\title{
Premnocarpon Mohgaoanii Gen. Et. Sp. Nov. A Report of Fossil Drupe Fruit From Deccan Intertrappean Beds of Mohgaonkalan, Dist. Chhindwara, M.P. India
}

\author{
S. W. Dighe ${ }^{1}$ and P. S. Kokate ${ }^{2}$ \\ ${ }^{1}$ Jijau Nagar,Dairy road, Nandura-443404, India \\ ${ }^{2}$ Department of Botany, Shri Shivaji College of Arts, Commerce and Science, Akola-444005, India
}

\begin{abstract}
A well preserved drupaceous fruit is collected from Mohgaonkalan, MP, India a well known Deccan Intertrappean Beds fossiliferous locality belonging to uppermost cretaceous period. The present fossil fruit is small, drupaceous, somewhat triangular fruit. Pyrene with single seed. Air spaces are present in the mesocarp. The fruit wall is divided into three zones, outer epicarp, middle mesocarp and inner endocarp. The reported fossil fruits shows affinities with fruits of Verbenaceae when resemblances are studied in detail at genus level, shows similarities with Premna and Premnocarpon as generic name.
\end{abstract}

Keywords: Angiosperms, Deccan, Drupe, Intertrappean, Premnocarpon, Verbenaceae

\section{Introduction}

The paper deals with the study of new pertified single seeded drupaceous fruit which was collected from Mohgaonkalan $\left(22^{0} 1^{\prime} \mathrm{N}^{\prime}, 79^{0} 11 \mathrm{E}\right)$ of the Deccan Intertrappean series, in Chhindwara, district of Madhya Pradesh India. The already reported drupaceaous fruits from same locality are Nautiyalocarpon singhpurii (Juneja, 1993), Erythroxylocarpon intertrappea (Khubalkar, 1982), Euphorbiocarpon drypetoids (Mehrotra et al., 1983), Biloculocarpon mohgaonse (Yawale, 1975), Biloculaire intertrappea (Kate, 1974) locality. Deccanocarpon arnoldii (Paradkar, 1975) Trapa mohgaonsis (Paradkar and Patki, 1987), Plectroniocarpon intertrappease (Kokate, et al., 2009), Scaevolocarpon indicum (Kokate et al., 2010), Verbenaceocarpon mahabalei (Dhabarde et al., 2012)

\section{Material And Methods}

A pertified fruit is preserved in black cherts exposed in longitudinal plane. After etching the cherts with hydrofluoric acid, serial peel sections are taken in longitudinal plane. The anatomical details were studied for the further discussion.

The present fossil fruit is described as-

\section{Description}

The fruit is small and somewhat triangular in shape and drupaceous tapering at base. (Text Fig. 1 and 2, Plate fig $1,2,3$ and 4 ). The size of the fruit is $1.99 \mathrm{~mm}$ in length and $1.46 \mathrm{~mm}$ in breadth.

Epicarp: Pericarp is smooth measuring $66.6 \mu$ in thickness. The outermost zone of pericarp is epicarp (Text Fig. 2, Plate Fig 5 ). The epicarp is thick having $7.98 \mu$ in thickness. The cells are small, fibrous and arranged in 2-3 layers. In this zone vasculature is not seen.

Mesocarp: The middle zone or mesocrp is thick $176.49 \mu \times 53.28 \mu$ in width. It consist of well developed parenchymathous tissue and fibrous tissue. The parenchymatous cells of this zone are thin walled, circular in shape and are also compactly arranged. The size of cells ranges from $0.133 \mu \times 0.153 \mu$ (Text Fig.3 and 4, Plate Fig 6 ). Mesocarp is also having three air spaces in fibrous tissues in the central part of fruit, measuring $41 \mu$ in length and $16 \mu$ in breadth in (Text fig. 3 and 5, Plate Fig.3 and 4) This cavity might be for the buoyancy for the dispersal of fruit.

Endocarp: The innermost zone or endocarp of pericarp is $9.31 \mu$ in thickness. The endocarp is very thin but hard and strong made up of cubical to rectangular cells.

The cells of endocarp thick walled, small and compactly arranged (Text fig 9, Plat Fig. 6 and 10 ). The size of the cell is $0.399 \mu$. Large seed occupies central cavity of fruit and measuring $136.53 \mu \times 73.26 \mu$ in size(Plate fig 8). The seed coat might be the innermost layer of pericarp. The seed coat is differentiated into testa and tegmen. Testa is 2-3 celled in thickness with brownish or yellowish contents in the (Plate Fig 5 ). It is very thick at the apical region while tegmen is not perominent represented by thin walled cells. The embryo is occupying seed cavity. Endosperm is not seen. The seed is observed in the pyrene. Inside the seed, embryo is seen having size $106.5 \mu$ x $56.61 \mu$.(Text fig 11 and 5, Plate fig 7 and 8) 
The observed characters of the fruit suggest a marshy habitat where they might have been growing. The presence of air spaces, spongy nature of fruit wall, fruits being fibrous drupes are all characteristics features resembles with the nature of flora and the marshy habitat.

\section{Discussion}

The characteristic features of the described fruit for identification are -

- The present fossil specimen is a small drupaceous and indehiscent fruit. It is small and somewhat triangular in shape with one pyrene, single seed in pyrene.

- Three small cavity i.e. air spaces is seen centre of fibrous tissue of fruit.

- The pericarp is with three differentied zones. i.e. epicarp, mesocarp and endocarp.

- The seed is solitory and unitegmic the embryo is occupying complete space of seed cavity. The seed coat has testa and tegmen. Testa is thick while tegmen is memberanous.

Form the above features it confirms as a drupaceous fruit with hard and stony endocarp. The fruit shows various degrees of resemblances to some families of order Rhamnales which is having unilocular ovary with one pyrene. When present fossil fruit compared with families of Rhamnales, Vitaceae family consist of fruit which is baccate, often watery, 1-6 celled, 1-2 seeded testa bony; embryo short, often ruminate albumen; cotyledons oval and all these characters do not match with described fossil fruit. When affinities of present fruit traced with family Rhamnaccae, fruit is having either an indehiscent and fleshy drupe with 1-4 indehisent pyrene (stones), embryo large. Seeds with this oily albumen. Sometimes exalbuminous, embryo straight or rarely bent.

The fruit shows affinities to some genera of family of Rhamnaeeae like Zizyphuys, Berchemia and Rhamuns. When present fruit compared with Zizyphus it show resemblances in having fleshy or soft corky mesocarp, endocarp cartilaginous and single stoned 1,2 or 3 loculed ovary. But differs in not having fibrous mesocarp and larger than present fossil fruit. When present fossil fruit is compared with Berchemia shows resemblances with having single stoned, mesocarp fleshy, endocarp stiffy but differs in having persistent calyx tube and remains remnant when present fossil fruit is compared with Rhamnus shows resemblances with the fruit in having berry like drupe and one seeded. Obovoid globose, stones indehiscent fruit but differs in having 2-4 stoned structure.

Hence, from the above described characters, structure of the present fossil fruit should be close to the genus Rhamnus of Rhamnace. When this fruit shows affinities to some genera of family of Verbenacaeae like Lantana , Calliarpa, Gmelina and Premna. When present fruit compared with Lantana shows resemblances with fruit type i.e. Drupe, and also with having hard endocarp but separating when ripe into 1- celled , 1- seeded pyrenes it is different from present fossil fruit . Lantana is having fleshy mesocarp while present fossil fruit is fibrous.

When present fossil fruit is compared with Collicarpa shows affinities in having fruit type drupe which is globous, oblong, 1- seeded, black in colour but differ in having 4- pyrene and larger in size. When present fossil fruit is compared with Gmelina shows resemblances with fruit type i.e. drupe succulent, undivided, endocarp bony, seed oblong but differ in having 2-4 celled and larger than present fossil fruit.

The present fossil fruit resembles with genus Premna in structure . some species of genus are growing along the sea shore in Kokan region suggesting marshy habitat. The present fossil fruit is also air spaces and fibrous mesocarp showing close affinities with the genus Premna from family Verbenaceae so named as Premnocarpon after the name of genus and species mohanii after the Deccan trap of India. The Verbenaceae family has prominent reported from the Cretaceous period .

\section{Comparison with other fossil fruits}

\section{Comparison}

When present fossil fruit compare with already reported Nautiyalocarpon singhpurii (Juneja, 1993), it shows close resemblances with having pericarp three layered, vascular supply present in between middle and inner layer of pericarp but differs in type of cells of pericarp. Erythroxylocarpon intertrappea (Khubalkar, 1982) is not comparable because of presence of indehiscent drupe.

When present fossil fruit compare with already reported Euphorbiocarpon drypetooids (Mehortra et al., 1983). It differes having a trilocular single seeded indehiscent drupe. And present fossil fruit shows unilocular single seeded drupe. Biloculocarpon mohgaonse (Yawale, 1975) is a bilocular drupe with canals arising from seed locules opening into mesocarp. Where as a fossil fruit is bilocular with single seed in each locule which is different from the present specimen. Already reported Biloculaire intertraappea (Kate, 1974) shows schizocarpic fruit with a single large seed in each locule and oil or resin ducts are present in outer and inner zone. The present fossil fruit shows single seeded indehiscent drupe.

When Trapa mohgaonsis (Paradkar and Patki., 1987) is compared with present fossil fruit shows similarities in having dicotyledons one seeded drupaceous and indehiscent fruit but differ in 2-3 spines with 
barbs. Plectroniocarpon intertrappease (Kokate et al., 2009) is already reported fossil shows similarities in ellipsoidal, drupaceous, indehiscent and single seeded drupe fruit. Areole is present in apical end but differs in having single pyrene and areole is present in middle part of fruit. Scaevalacarpon indicum (Kokate et al., 2010) shwos similarities in unilocular single seeded drupe with air cavities in pericarp but differ in having air cavities in central part of pericarp.

Verbenaceocarpon mahabalei (Dhabarde et al., 2012) already reported a fossile fruit is compared with a present fossil fruit it show similarities in type of fruit is drupe but differs in number of locules that is present fruit is unilocular one seeded. The earliest fossil record of family Rhamnaceae is reported from the upper cretaceous period (Kapgate, 2005). The various plant parts of family Rhamnaceae are reported from deccan intertrappean beds of India such as Zizyphoxylon mandelaensis from Parapani (Trivedi and Shrivastava, 1982) Zizyphus ambabagholi near Baitul (Gaikwad and Patil, 1993) and Rhamnoxylon intertrappea from Mohgaonkalan (Chitaley and Kate, 1972).

Impressions are interpretated as Rhamanceous fruit have also been reported from middle Jurassic of North China, infact these fossils, are remains of angiospermous fruits, then it goes without saying that their Jurassic are greatly predactes demonstable megafossil evidence of the flowering plant (Edith, Thoms Taylor, Michael, 2009) Already reported Pyrenocarpon harisii (Thorat , 2015) presence of pyrene of Rhamnaceae family differs in size from present fossil fruit. From the above comparison and discussion, it observed that the fossil fruit is more or less similar to fruit of Rhamnus species of Rhamnaceae family.

\section{Premnocarpon gen. nov.}

\section{Diagnosis}

Fruit small dicotyledonous drupaceous, indehiscent and some what trianglular in shape. It is subglobose, ovoid with pyrene with single seed. Air space is present at the centre of mesocarp. The pericarp divided into three zones. Outer epicarp, middle mesocarp and inner endocarp. The seed is solitory and unitegmic. The seed coat consisting of testa and tegmen.

\section{Premnocarpon mohagaonii gen. et sp. nov.}

Fruit triangluar, drupaceous, rounded base measuring $1.99 \mathrm{~mm}$, in length and $1.46 \mathrm{~mm}$ in breadth. Pericarp about $66.6 \mu$ in thickness, epicarp $7.98 \mu$; mesocarp 176.49 × $53.28 \mu$ and endocarp $9.31 \mu$ in thickness. Seed solitary and seed coat consisting testa and tegmen, endosperm not seen . Embryo with cotyledons measuring $\quad 106.56 \times 56.61 \mu$ in size.

Holotype - MOH/SWD/DICOT/FRUIT-2

Department of Botany, Shri. Shivaji College Akola

Locality - Mohgaonkalan, District Chhindwara, M. P. India

Horizon - Deccan Intertrappean Bed, India

Age - Upper Cretaceous

\section{References}

[1]. Dhaberde, P. F., Sheikh, M.T. and Kolhe, P.D. 2012. A petrified bilocular fruit from the Deccan Intertrappean beds of Singpur, Madhya Pradesh. Bio. Innov. 1 (1) :1-5.

[2]. Edith, L. layer, Thoms N. Taylor Michel, 2009. Paleobotany : The Biology and Evolution of fossil plants. King Academic Press.

[3]. Gaikwad, B.B. and Patil, G.V. 1993. On two dicot woods from the Itertrappean Beds of Ambabagholi, Dist. Baitul, M.P. Gond. Geol. Magz. $6: 27-41$

[4]. Juneja, C.D. 1993. Study of the uppermost Cretaceous Intertrappean flora of central India. Ph. D Thesis, Nagpur University, Nagpur.

[5]. Khubalkar, N.V. 1982. Petrifird plants from Mohgaonkalan, bed of M.P. India, Ph.D Thesis, Nagpur University, Nagpur.

[6]. Kate, V.R. 1974. Studies of Deccan Intertrappean flora of India. Ph. D. Thesis, Ngpur University, Nagpur.

[7]. Kapgate, D. K., Patil, S. P., I lamkar, N.P., Ramteke, D.D. 2006 . Investigation of new petrified Trilocular fruit from the Deccan Intertrappean series of Mohgaonkalan, M.P., Paleobotany to modern botany, Pointer Publishers Jaipur 302003 (Raj.) India.

[8]. Kokate, P.S., Upadhye, E.V. and Patil G.V. 2010. A Dicotyledonous drupaceous fossil fruit Scaevolacarpon indicum gen. et.sp. nov. from Mohgaonkalan M.P. India, Bioinfolet. 7(1) : 59-63.

[9]. Mehrotra, R.C. 1993. Euphorbiocarpon drypteoids gen. et sp. nov. a new Euphorbiaceous fruit from the Deccan Intertrappean beds of Mandala district, M.P. Geophytology, $13: 127-133$.

[10]. Paradkar, S.A., 1975. Deccanocarpon arnoldii gen. et. sp . nov . A new dicotylrdonous fruit from the Deccan Intertrappean series of India. The Botanique. 6(1) : 5-10.

[11]. Paradkar, S.A. and Patki, S.P. 1987. Trapa mohgaonsis, A new petrified dicotyledonous fruit from the Deccan Intertrappean beds of Mohgaonkalan, M.P. India. Geophytology.17(1): 21-27.

[12]. Trivedi, B.S. and Shrivastava, K., 1982. Zizyphoxylon mandlaensis gen. et sp. Nov. from the Deccan Intertrappean beds of Mandalla Distirct M.P. Jour. Ind. Bot. Soc., $61: 212-215$.

[13]. Thorat, K.M. 2015 . Morphological studies of fossil flora fro Deccan Intertrappean beds of Mohgaonkalan, M.P., India Ph. D. Thesis Amravati University, Amravati.

[14]. Yawale, N.R., 1975 Investigation of plant fossil from the Intertrappean series of India Ph. D. Thesis, Nagpur University, Nagpur of plant fossil. 
Premnocarpon deccanii gen. et. sp. nov.
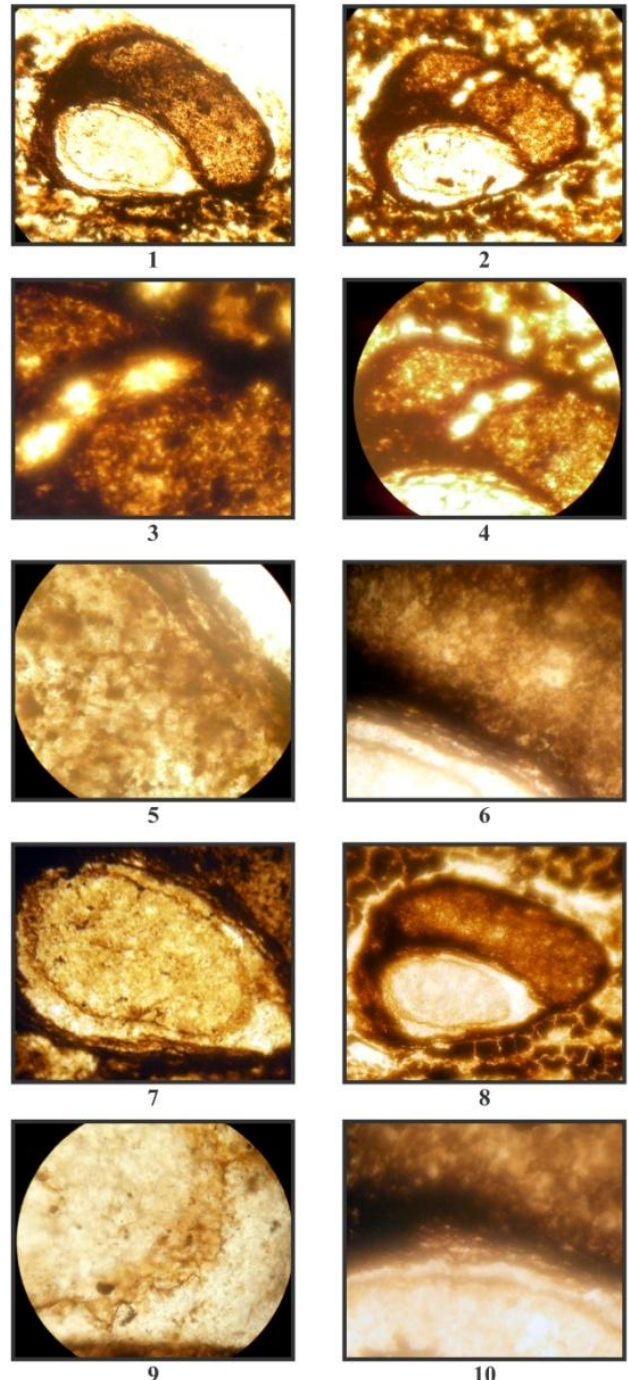

Explanation of Plate Figure 1 - 10

1,2 : L.S. of complete fruit showing epicarp, mesocare and endocarp and air species $\times 20$ $1,2:$ L.S. of complete fruit showing epicarp, mesocarp and endocarp and air species $\times 20$;
$3,4:$ L.S. of fruit showing air spaces in mesocarp x $100 ; 5:$ L.S. of fruit showing thick walled cells of epicapr $\times 50 ; 6:$ L.S. of fruit showing hard, stony layer of endocarp $x 100 ;$
c. $7,8:$ L.S. of fruit showing seed cavity and embryo with seed coat $x 50$;
: 7,8: L.S. of fruit showing seed cavity and embryo with seed coat x 50 ;
9: Cells of embryo x100; 10 : Magnified structure of encocarp x 100 
Premnocarpon deccanii gen. et. sp. nov.
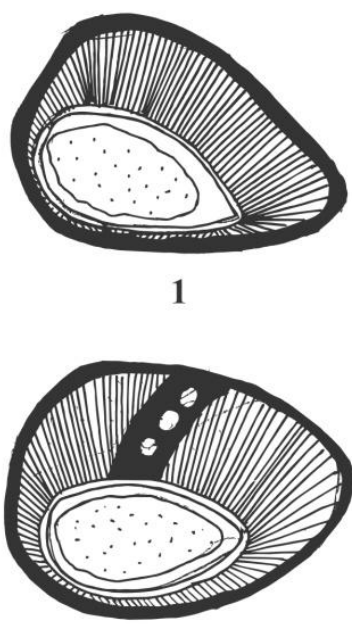

3

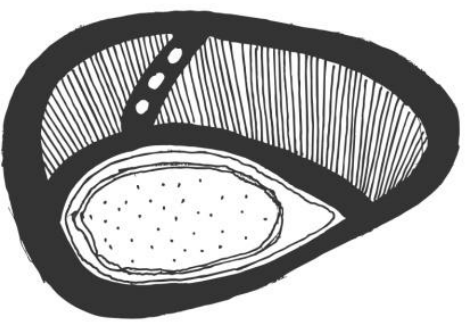

5

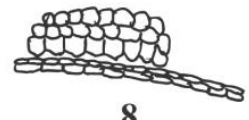

8

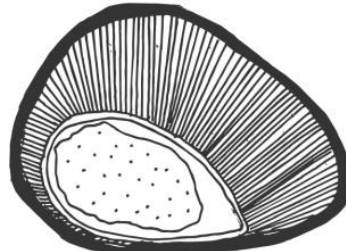

2

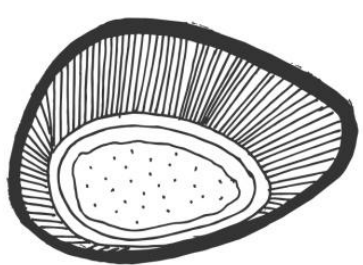

4

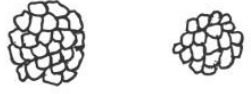

6

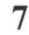

Explanation of Text Figure 1 - 10

1-4 : Serial section L.S. of fruit showing complete structure (epicarp, mesocarp with air spaces, endocarp, seed with embryo)

5 : L.S. of fruit showing seed with seed coat and embryo

6 : Cellular details of mesocarp

7 : Cells of seed cavity

8 : Cells of seed coat

9 : Cells of endocarp

10 : Cells of seed

11 : Cells of embryo

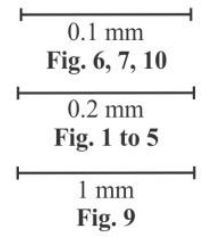

